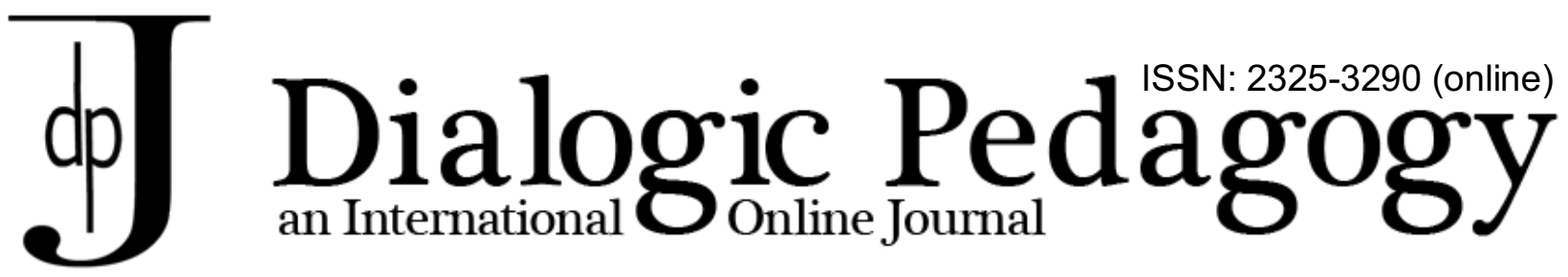

\title{
Ideological Becoming in Socialist and Post-Socialist Childhood and Schooling from a Dialogic Framework
}

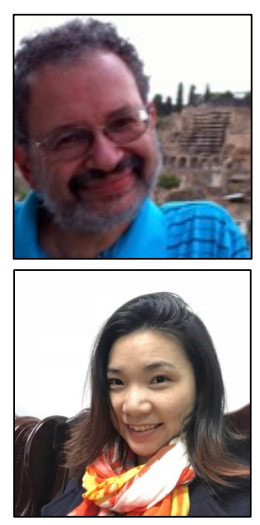

Eugene Matusov

University of Delaware, USA

Lei Chen

Shaanxi Normal University, China

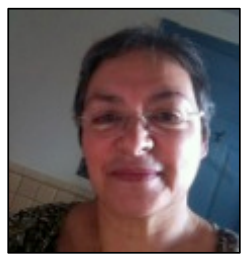

Ana Marjanovic-Shane

Independent Scholar, USA

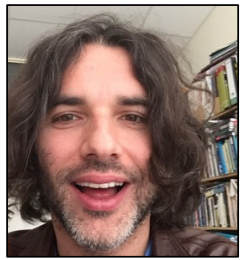

Marek Tesar

The University of Auckland, New

Zealand

\begin{abstract}
This special DPJ issue aims to bring together those who had first-hand experiences with or conduct educational and/or historical research with children and schooling in socialist and post-socialist societies. Socialist and post-socialist childhood and schooling in socialist and post-socialist education systems are usually assumed to be monolithic and authoritarian, far from dialogic. However, by reflecting on our own or others' experiences, narratives and observations regarding the socialist and post-socialist childhood, we realized that our memories, experiences and observations might offer unique and enriching soil for understanding, exploring, reflecting, and critiquing dialogic pedagogical theories. Through this special issue, we hope to expand the scholarship of this community to the territory of a space and time that were not previously examined (sufficiently) for dialogic pedagogy by creating interests and forums for dialogues.
\end{abstract}

$\cos \cos 80$

\section{Introduction}

According to Bakhtin (1986) and Medvedev (1985), "ideological becoming" is the formation of ideological subjectivity within the historical, political and cultural "ideological environment," in which an individual lives. This formation is both reactive, emergent, and proactive, dialogic. Individual ideological subjectivity is shaped and constrained by its historical, political and cultural ideological environment. However, at the same time an individual creatively and at times dangerously transcends her/his ideological environment in her/his ideological becoming.

Among other things, the $X X$ century was characterized by the emergence and then decline of the so-called real socialism political and economic regimes. We feel it is important to document and analyze Ideological Becoming in Socialist and Post-Socialist Childhood and Schooling from a Dialogic Framework, while participants are still available.

This special DPJ issue aims to bring together those who had first-hand experiences with or conduct educational and/or historical research with children and schooling in socialist and post-socialist societies. Socialist and Post-Socialist childhood and schooling in socialist and post-socialist education systems are 


\section{Ideological Becoming in Socialist and Post-Socialist Childhood \\ Eugene Matusov, Ana Marjanovic-Shane, Lei Chen, Marek Tesar}

usually assumed to be monolithic and authoritarian, far from dialogic. However, by reflecting on our own or others' experiences, narratives and observations of socialist and post-socialist childhood, we realized that our memories, experiences and observations might offer unique and enriching soil for understanding, exploring, reflecting, and critiquing dialogic pedagogical theories. Through this special issue, we hope to expand the scholarship of this community to the territory of a space and time that were not previously examined (sufficiently) for dialogic pedagogy by creating interests and forums for dialogues.

Following are a few exemplary (non-exclusive) questions that we are interested to explore in this special issue:

1. How did the dialogical (monological) schooling, parenting and child-caring made children social and political?

2. How did children (students) and teachers construct dialogues with the confinements of and the opportunities provided by the space, time and everyday lives in (post)socialist childhood (including family lives, parenting and school lives, museums, specialized/elite schools, camps, collective farms, after-school activities, etc.)?

3. How did diversity-language, sexuality, gender, ethnicity, race, (dis)ability, and other factors of diversity influence the construction and people's participation of dialogues in (post)socialist schooling?

4. What lessons can be learned from (post)socialist childhood that might challenge our understanding of how learning, schooling, and dialogues are influenced by the political regimes in the past and today's world?

We understand that there are as many contradictions, complexities and dualisms in (post)socialist childhood as in dialogic pedagogy, we welcome scholars in a diversity of fields of studies to contribute to this special issue. Thereby, we loosely define "dialogic pedagogy" as any scholarship and pedagogical practice, from educational researchers, philosophers, and practitioners, which values and gives priority to "dialogue" in learning/teaching/educating across a wide range of institutional and non-institutional learning settings.

We welcomed authors' experimentation and creativity in genres and approaches to their autobiographical research and writing - a variety of sources of narratives including (but not limited to) autoethnographic accounts, collective biography, qualitative interviews, historical analysis, and discourse analysis.

The following authors approached their auto-ethnographies in multidisciplinary ways emphasizing diverse disciplines of social studies such as history, anthropology, sociology, linguistics, social work, psychology, political science, gender studies, philosophy, and so on. 
Ideological Becoming in Socialist and Post-Socialist Childhood

Eugene Matusov, Ana Marjanovic-Shane, Lei Chen, Marek Tesar

\section{(cc) EY}

New articles in this journal are licensed under a Creative Commons Attribution 4.0 United States License.
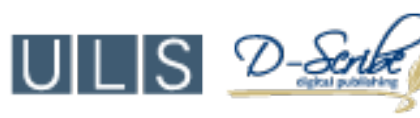

This journal is published by the University Library System, University of Pittsburgh as part of its D-Scribe Digital Publishing Program and is cosponsored by the University of Pittsburgh Press 